PRACE GEOGRAFICZNE

zeszyt $160,2020,9-27$

doi: 10.4467/20833113PG.20.001.12259

Instytut Geografii i Gospodarki Przestrzennej UJ

Komisja Geograficzna, Polska Akademia Umiejętności

Wydawnictwo Uniwersytetu Jagiellońskiego

\title{
JAKOŚĆ OBSŁUGI KLIENTA W BIURACH PODRÓŻY - PRZYKŁAD KRAKOWA
}

\author{
Kinga Kræesiwo, Anna Zaremba
}

\section{Quality of customer service in travel agencies - case study of Krakow}

Abstract: The paper concerns the quality of customer service in tourist services. The aim of this study is to present an assessment of the quality of customer service in selected travel agencies in Krakow. The spatial extent of research involved the Old Town with adjacent quarters and the Kazimierz district in Krakow. To achive the purpose of the work, a stocktaking of travel agencies and an assessment of the quality of customer service using a mystery shopping method were carried out from March to May 2019. The quality of customer service in Krakow's travel agencies is varied. It is at an average but increasingly unsatisfactory level. Network travel agencies have a higher standard of customer service than non-network ones. The top-rated areas of customer service were staff appearance as well as their behaviour and personal culture during the conversation with a client. The lowest-rated areas were staff behaviour and personal culture during the customer enterance to the office as well as at the end of the conversation and while saying goodbye to the client. Only $16,0 \%$ of studied travel agencies showed maximum interest and respect to the customer. The research results presented in this paper can be used in the functioning of travel agencies in Poland to improve the quality of services in these types of enterprises and meet the requirements of quality management.

Keywords: quality, customer service, travel agency, mystery shopping, Krakow

Zarys treści: W artykule podjęto zagadnienie jakości obsługi w usługach turystycznych. Celem artykułu jest przedstawienie jakości obsługi klienta w wybranych biurach podróży 
w Krakowie. Zakres przestrzenny badań obejmował Stare Miasto z kwartałami przylegającymi oraz Kazimierz. Do osiągnięcia celu pracy przeprowadzono inwentaryzację biur podróży na badanym terenie oraz ocenę jakości obsługi klienta metodą mystery shopping (,tajemniczego klienta”) w 25 krakowskich biurach podróży specjalizujących się w turystyce wyjazdowej. Badania prowadzono od marca do maja 2019 r. Jakość obsługi klienta w krakowskich biurach podróży jest zróżnicowana. Kształtuje się ona na średnim poziomie. Wyższy standard obsługi prezentują biura sieciowe niż niesieciowe. Najlepiej ocenionymi obszarami obsługi klienta były wygląd pracowników oraz ich zachowanie i kultura osobista w trakcie prowadzenia rozmowy z klientem, a najsłabiej - zachowanie i kultura osobista personelu w chwili wejścia klienta do biura oraz przy zakończeniu rozmowy i pożegnaniu klienta. Maksimum zainteresowania i szacunku, przez co klient czuł się jak ktoś wyjątkowy, okazano mu średnio w co szóstym badanym obiekcie. Zaprezentowane w artykule wyniki badań mogą zostać wykorzystane w działalności biur podróży w całej Polsce w celu podniesienia jakości świadczonych usług w tych przedsiębiorstwach i sprostania wymaganiom zarządzania jakością.

Stowa kluczowe: jakość, obsługa klienta, biuro podróży, badania „tajemniczego klienta”, Kraków

\section{Wprowadzenie}

Współcześnie jakość odgrywa ważną rolę w procesie postępującej dywersyfikacji potrzeb ludzkich. Należy ona do najistotniejszych efektów różnego rodzaju działalności, w tym działalności usługowej. Obok ceny jest podstawowym czynnikiem decydującym o rodzaju zakupów dokonywanych przez klientów (Panasiuk 2006; Szostak, Panasiuk 2007). Dostarczanie konsumentom produktów i usług o najwyższej jakości jest podstawowym warunkiem przetrwania na coraz bardziej konkurencyjnym rynku (Baum, Kokkranikal 2008). Wobec rosnącego nacisku na wysoką jakość, branże usługowe, w tym turystyka, powinny traktować ją jako kwestię strategiczną z punktu widzenia oferowania wieloaspektowych możliwości budowania przewagi konkurencyjnej (Gamble, Jones 1991; Rapert, Wren 1998).

W dziedzinie turystyki jakość stanowi kluczowy warunek sukcesu rynkowego, a kluczem do wysokiej jakości są zasoby ludzkie (Poon 1993). Świadczenie wysokiej jakości usług w dużej mierze zależy od personelu, który jest swoistą wizytówką przedsiębiorstwa w kontaktach z klientami. Istotne znaczenie pracowników obsługujących klientów w przedsiębiorstwach turystycznych wynika z faktu, że na rynku usług turystycznych dochodzi do bezpośredniego kontaktu personelu z klientem. Od kompetencji, zachowania i prezencji personelu zależy jakość oferowanych usług, zadowolenie klientów i korzystny wizerunek przedsiębiorstwa w otoczeniu. Osoba dobrze przygotowana do obsługi ruchu turystycznego, jej zachowanie i wygląd pozostają w pamięci klientów i kojarzą się z firmą, którą ona reprezentuje (Baum, Kokkranikal 2008; Panasiuk 2006; Tokarz 2007). Poprzez odpowiednią obsługę klientów w przedsiębiorstwach turystycznych, pracownicy oddziałują na postrzeganie jakości usługi przez klienta. Wysoka jakość obsługi staje się zatem jednym 
z ważniejszych czynników, które wyróżniają przedsiębiorstwo spośród konkurencji, a tworzenie wysokich standardów obsługi klienta jest jednym z najważniejszych sposobów pozyskania nowych i utrzymania dotychczasowych klientów (Panasiuk 2006; Tokarz 2007).

Świadczenie usług turystycznych na jak najwyższym poziomie jest korzystne dla przedsiębiorstwa nie tylko z marketingowego, ale także z ekonomicznego punktu widzenia. Według Szostaka (2007, s. 78) košt pozyskania nowego klienta

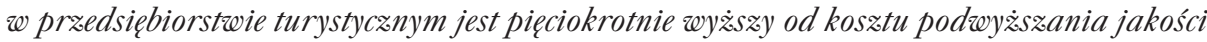
ustug w celu utrzymania obecnego klienta. Dzieje się tak z dwóch głównych powodów. Po pierwsze, stali klienci są w stanie zapłacić więcej za wyższą jakość, ponieważ korzystali już wcześniej z usług w danym obiekcie i byli z nich zadowoleni. Po drugie, obecni klienci zapewniają firmie darmową reklamę poprzez informowanie innych o poziomie usługi i zadowoleniu z końcowego efektu.

Zadowolenie klienta z dostarczonej mu usługi jest jednym z czynników emocjonalnych wynikających z jakości świadczonych usług (Lovett i in. 2013), a wpływających na lojalność konsumentów i polecenie danej usługi osobom trzecim (Krzesiwo 2018; Żemła 2010). Współcześnie najskuteczniejszą formą marketingu jest tzw. marketing szeptany (word of mouth marketing), który polega na przekazywaniu informacji o danej usłudze lub produkcie obecnym i potencjalnym klientom w naturalny, niewymuszony sposób, np. podczas rozmowy (Lovett i in. 2013; Rosen 2000). Opinia znajomych i członków rodziny jest najważniejszym źródłem, z którego klienci czerpią informację o jakości usług świadczonych w przedsiębiorstwach działających w branży turystycznej. Klienci szukają opinii innych osób, ponieważ są one bardziej wiarygodne niż przekaz reklamowy. Im wyższy poziom zadowolenia klientów z usług turystycznych, tym pewniejsze, że zostaną one zarekomendowane poprzez przekaz ustny ich znajomym lub rodzinie, a przez internet także innym osobom (Krzesiwo 2014, 2018). Z tego punktu widzenia monitorowanie jakości obsługi klienta w przedsiębiorstwach usługowych, w tym turystycznych, ma istotne znaczenie dla ich rozwoju i wzrostu przewagi konkurencyjnej na stale zmieniającym się rynku.

W teorii zarządzania istnieje rozbudowany zbiór instrumentów służących pomiarowi i ocenie jakości usług (Dziadkowiec 2006b; Stoma 2012). Wśród narzędzi wykorzystywanych w badaniu jakości obsługi klienta stosuje się metody subiektywne i obiektywne. Najpopularniejszą i najczęściej używaną metodą subiektywną jest metoda SERVQUAL ${ }^{1}$. Polega ona na pomiarze różnicy pomiędzy usługą oczekiwaną przez klienta a usługą otrzymaną (Bielawa i in. 2009; Dziadkowiec 2006b; Stoma

\footnotetext{
$\overline{1}$ SERVQUAL (ang. Service Quality) to metoda badania jakości usług opracowana w 1985 r. przez V. Zeithaml, A. Parasurmana i L. Berry'ego z Uniwersytetu w Miami (USA). Polega ona na pomiarze jakości przez porównanie oczekiwań klienta przed wykonaniem usługi i jego odczuć z otrzymanej usługi. Autorzy metody wskazali na 5 typów sytuacji, tzw. 5 luk, których istnienie powoduje niezadowolenie klienta i skutkuje niską oceną jakości usług (Bielawa i in. 2009; Dziadkowiec 2006b; Stoma 2012; Urbaniak 2013).
} 
2012; Urbaniak 2013). Natomiast wśród metod obiektywnych najczęściej stosowaną jest metoda mystery shopping, czyli „tajemniczego klienta” (Dziadkowiec 2004, 2006b; Karaszewski 2001; Stoma 2012). Ta metoda badania jakości usług została stworzona jako opcja alternatywna do badań ankietowych konsumentów. W metodzie tej miejsce klienta zajmuje wyszkolony ankieter - „tajemniczy klient”, który korzystając z usług jak zwykły klient, później wypełnia kwestionariusz, oceniając poszczególne etapy usługi. Osoba obsługująca klienta nie wie, że jest sprawdzana, przez co nie stara się wypaść lepiej niż zazwyczaj. W przypadku tej metody ograniczona zostaje subiektywność klienta, gdyż „tajemniczy klient” powinien być neutralny, tzn. nie może kierować się emocjami, lecz faktami (Dziadkowiec 2006b).

Badania jakości obsługi klienta w usługach turystycznych metodą mystery shopping stosuje się dość często. Przeprowadzane są one przeważnie przez firmy badawcze na zlecenie właścicieli przedsiębiorstw turystycznych i organizacji turystycznych. Te wykonywane dla właścicieli przedsiębiorstw stanowią ich prywatną własność, dlatego też wyniki badań nie są publikowane. Natomiast te prowadzone dla organizacji turystycznych są upowszechniane w formie raportów. W ostatnich latach dla Polskiej Organizacji Turystycznej realizowano badania metodą „tajemniczego klienta”, m.in. w jednostkach informacji turystycznej. Celem tych badań była ocena jakości obsługi klienta podczas wizyty klienta w placówce, ocena wykorzystania poczty elektronicznej w trakcie pierwszego kontaktu z potencjalnym klientem oraz ocena skuteczności kontaktu telefonicznego, formy i jakości przekazywanych informacji podczas rozmowy telefonicznej (Raport z badań ... 2013; Tajemniczy klient w jednostce Informacji Turystycznej... 2019; Tajemniczy klient w placówce IT ... 2017). Studia dotyczące oceny obsługi klienta w turystyce metodą „tajemniczego klienta” najczęściej odnosiły się do usług gastronomicznych. Badania były przeprowadzane głównie w restauracjach (Chen, Barrows 2015; Dziadkowiec 2011; Dziadkowiec, Rood 2010; Su, Tsai 2014; Wszendybył-Skulska 2015) i pizzeriach (Mazurkiewicz-Pizło, Pizło 2018). Znacznie mniej publikacji dotyczących tego tematu powstało w odniesieniu do biur podróży (Dziadkowiec 2000; Mazurek-Kusiak 2012), obiektów noclegowych, w tym hoteli i gospodarstw agroturystycznych (Jackiewicz, Dębski 2015; Kosmaczewska 2011; Mroczkowska, Pawlicz 2012) oraz atrakcji turystycznych (Kruczek, Cieszkowska 2017; Kruczek, Szromek 2014).

Analiza jakości obsługi klienta dostarcza cennych informacji dotyczących świadczonych usług. Stanowi ona istotną część planowania strategii zarządzania jakością, gdzie orientacja na potrzeby klienta jest motywem wiodącym i umożliwia zminimalizowanie ryzyka spadku lub braku lojalności klientów. W warunkach konkurencji i stale zmieniającego się otoczenia, z punktu widzenia funkcjonowania przedsiębiorstw, w tym przypadku biur podróży, ocena jakości obsługi klienta jest kwestią niezwykle istotną. Właśnie podczas pierwszego kontaktu pracownika z potencjalnym klientem, turysta wyrabia sobie opinię na temat oferty i całego biura. Jest to zatem moment decydujący, czy dokona on zakupu (Dziadkowiec 2006a). Poprzez ciągłe 
dostarczanie usług o wysokiej jakości przedsiębiorstwa zyskują lojalność wśród nabywców. Ta z kolei przynosi im korzyści w formie udziałów w rynku, zysków, niskich kosztów pozyskania i utrzymania klientów, a w rezultacie lepsze płace dla pracowników (Kachniewska 2004).

\section{Cel i metodyka badań}

Celem artykułu jest przedstawienie jakości obsługi klienta w wybranych biurach podróży w Krakowie. Zakres przestrzenny badań obejmował Stare Miasto wraz z kwartałami przylegającymi (do tzw. drugiej obwodnicy) oraz Kazimierz. Wybór obszaru badań był podyktowany faktem, iż w wymienionych częściach miasta, pełniących funkcję centrum usługowego i handlowego, obserwuje się największe skupienie biur podróży (Waloryzacja præestræeni miejskiej Krakowa ... 2008).

Do zrealizowania celu pracy posłużono się metodami badawczymi dostosowanymi do wymagań procesu badawczego, który obejmował trzy etapy. W pierwszym etapie pracy (marzec-kwiecień 2019 r.):

- przeprowadzono kartowanie i inwentaryzację biur podróży na badanym terenie, - przygotowano kwestionariusz oceny obsługi klienta,

- wykonano badania pilotażowe,

- doprecyzowano zakres i układ kwestionariusza oceny.

W drugim etapie, zrealizowanym w maju 2019 r., przeprowadzono badania oceny jakości obsługi klienta metodą mystery shopping („tajemniczy klient”) w 25 krakowskich biurach podróży, specjalizujących się w turystyce wyjazdowej. Trzeci etap pracy (czerwiec-wrzesień 2019 r.) obejmował stworzenie bazy danych pochodzącej z przeprowadzonych badań terenowych oraz kameralne opracowanie materiałów źródłowych.

Badania metodą mystery shopping polegały na prowadzeniu obserwacji biernej, kiedy osoba realizująca badanie obserwowała, jak obsługiwani byli klienci, oraz obserwacji uczestniczącej, kiedy ta sama osoba wcielała się w rolę klienta. Podczas audytu w biurach podróży „tajemniczy klient” występował jako potencjalny klient, który był zainteresowany zakupem wczasów zagranicznych. Audytor prowadził wizytę zgodnie z wcześniej ustalonym scenariuszem, a następnie po jej zakończeniu i po wyjściu z danej placówki notował wyniki we wcześniej przygotowanym kwestionariuszu. Kwestionariusz ten był wzorowany na podobnych narzędziach wykorzystywanych w ocenie obsługi klienta w usługach turystycznych, dostosowany został do specyfiki usług świadczonych przez biura podróży. W każdym z badanych biur podróży realizowano jeden pomiar. Badania były prowadzone każdorazowo przez jedną osobę. Średnia długość wizyty wynosiła 18 minut. Najkrótsze badanie trwało 5 minut, a najdłuższe 40 minut. 
Kwestionariusz oceny podzielono na osiem części. W części pierwszej, tzw. metryczce, znajdowały się podstawowe informacje dotyczące badanego biura podróży, takie jak: nazwa i adres biura, imię ocenianego pracownika, liczba stanowisk przeznaczonych do obsługi klienta, godzina wejścia i wyjścia audytora. W kolejnych częściach dokonywano oceny danej placówki pod kątem następujących cech: wygląd i zagospodarowanie otoczenia lokalu, prezentacja witryny, wystrój i zagospodarowanie wnętrza lokalu, wygląd personelu, zachowanie i kultura osobista personelu (po wejściu klienta do biura, podczas prowadzenia rozmowy i prezentowania oferty, przy zakończeniu rozmowy i pożegnaniu klienta), umiejętności personelu odnośnie do badania potrzeb klienta i przedstawienia oferty, zadowolenie klienta z obsługi w biurze podróży. Kwestionariusz składał się z 76 pytań zamkniętych. W 75 pytaniach możliwymi odpowiedziami były „Tak” lub „Nie”. Za odpowiedź „Tak” przyznawano 1 punkt, a za odpowiedź „Nie”- 0 punktów. Ostatnie pytanie odnosiło się do ogólnej satysfakcji „,tajemniczego klienta" dotyczącej obsługi w badanym biurze podróży. Swoją subiektywną ocenę i odczucia miał wyrazić w pięciostopniowej skali, gdzie ocena 1 oznaczała zdecydowane niezadowolenie, a ocena 5 - zdecydowane zadowolenie z obsługi. Każde oceniane biuro mogło uzyskać maksymalnie 80 punktów.

\section{Biura podróży w Krakowie}

Pojęcie „biuro podróży” stosuje się najczęściej w nawiązaniu do podmiotu gospodarczego zajmującego się organizacją imprez turystycznych i pośrednictwem turystycznym (Konieczna-Domańska 2008; Pawlusiński 2007; Szymańska 2008). Z ogólnego terminu „biura podróży” wydziela się organizatorów turystyki i agentów turystycznych. Organizatorzy turystyki łączą pojedyncze usługi turystyczne w pakiety turystyczne w celu ich dalszej sprzedaży, natomiast agenci turystyczni pośredniczą w sprzedaży usług turystycznych w imieniu i na zlecenie organizatora turystyki lub innego podmiotu świadczącego usługi turystyczne (Pawlusiński 2007). Przepisy dotyczące norm działania firm turystycznych oraz warunków świadczenia usług turystycznych przez przedsiębiorstwa turystyczne w Polsce i za granicą do 2017 r. regulowała Ustawa o ustugach turystycznych z dnia 29 sierpnia 1997 r. (Dz.U. $1997 \mathrm{Nr} 133$ poz. 884). 24 listopada 2017 r. wprowadzono w życie Ustawe o imprezach turystycznych i powiqzanych ustugach turystycznych (Dz.U. 2017 poz. 2361). Wdrożyła ona do polskiego porządku prawnego postanowienia Dyrektywy Parlamentu Europejskiego i Rady UE nr 2015/2302/: dnia 25 listopada 2015 r. w sprawie imprez turystycznych i powiqaanych ustug turystycznych. 1 lipca 2018 r. uchylono przepisy Ustawy o ustugach turystycznych z dnia 29 sierpnia 1997 r., dotyczące organizatorów turystyki, pośredników turystycznych oraz agentów turystycznych. Najważniejsza zmiana wprowadzona przez nową Ustawe o imprezach turystycznych i powiqzanych ustugach turystycznych dotyczyła objęcia regulacją podmiotów, 
których dotąd nie obowiązywała Ustawa o ustugach turystycznych. Od 1 lipca 2018 r. przepisami objęci są wszyscy, którzy organizują imprezy turystyczne lub ułatwiają nabycie powiązanych usług turystycznych, w tym także na zasadach niekomercyjnych (Dyka 2018). Obecnie w polskim prawie wyróżnia się trzy rodzaje biur podróży. Należą do nich: organizatorzy turystyki, agenci turystyczni i przedsiębiorcy ułatwiający nabywanie powiązanych usług turystycznych.

W 1983 r. w Krakowie istniało 15 placówek zajmujących się obsługą ruchu turystycznego (Atlas Miasta Krakowa 1988). Zlokalizowane były głównie w obrębie Starego Miasta. Intensywny rozwój infrastruktury turystycznej, w tym podmiotów świadczących usługi w zakresie organizacji imprez turystycznych oraz szeroko rozumianego pośrednictwa turystycznego, nastąpił w latach 90. XX w. oraz w pierwszej dekadzie XXI. Według Pawlusińskiego (2011) w 2008 r. w Krakowie działało 295 biur podróży, w tym 209 organizatorów turystyki i pośredników turystycznych oraz 82 agentów turystycznych. Ponad połowa (56\%) z nich prowadziła swoją działalność w odrębnych lokalach usługowych. Zlokalizowane były głównie w obrębie Starego Miasta, Kazimierza i w kwartałach przylegających (do tzw. drugiej obwodnicy). W pierwszych latach XXI w. zaobserwowano także rosnącą tendencję do lokalizowania tego typu podmiotów w nowo powstających centrach handlowo-rozrywkowych i w ich bezpośrednim sąsiedztwie. Ponad 3/4 zarejestrowanych w Krakowie biur podróży specjalizowało się w organizacji turystyki wyjazdowej.

$\mathrm{Z}$ przeprowadzonych badań inwentaryzacyjnych wynika, że na badanym obszarze w 2019 r. działało 78 biur podróży (ryc. 1). Aż 43,6\% z nich znajdowało się tylko przy sześciu ulicach: Karmelickiej (8 obiektów), Długiej (7), Starowiślnej (5) oraz Floriańskiej (6), Grodzkiej (4) i Mikołajskiej (4). Zdecydowaną większość (93,6\%) stanowiły biura małe, w których znajdowały się 1-3 stanowiska przeznaczone do obsługi klientów. Zaledwie 6,4\% biur miało 4 lub więcej takich stanowisk. Biorąc pod uwagę podział biur podróży ze względu na to, czy są one organizatorami i przedsiębiorstwami ułatwiającymi nabywanie usług turystycznych, czy agentami turystycznymi, średnio co czwarte $(23,0 \%)$ z nich należało do pierwszej wymienionej grupy. Największe skupisko takich podmiotów było przy ul. Karmelickiej (5) i w Galerii Krakowskiej (4). Większość zlokalizowanych na badanym obszarze biur podróży $(80,8 \%)$ specjalizowała się w organizacji turystyki wyjazdowej. Obsługą przyjazdowego ruchu turystycznego zajmowało się średnio co piąte biuro (19,2\%). Aż 10 z 15 biur oferujących usługi w zakresie turystyki przyjazdowej miało swoją siedzibę na Starym Mieście, w tym 5 przy ul. Floriańskiej i 2 przy ul. Grodzkiej. Z punktu widzenia podziału biur podróży na sieciowe i niesieciowe, na badanym obszarze zdecydowanie więcej $(84,6 \%)$ istniało tych obiektów należących do drugiej grupy. Sieciowe biura podróży (12 obiektów), z wyjątkiem jednego, były położone poza obszarem Starego Miasta. Najwięcej takich biur mieściło się w Galerii Krakowskiej (4), przy ul. Karmelickiej (3) i ul. Stradomskiej (2). Należały one głównie do sieci: ITAKA, Neckermann, Rainbow i TUI. 


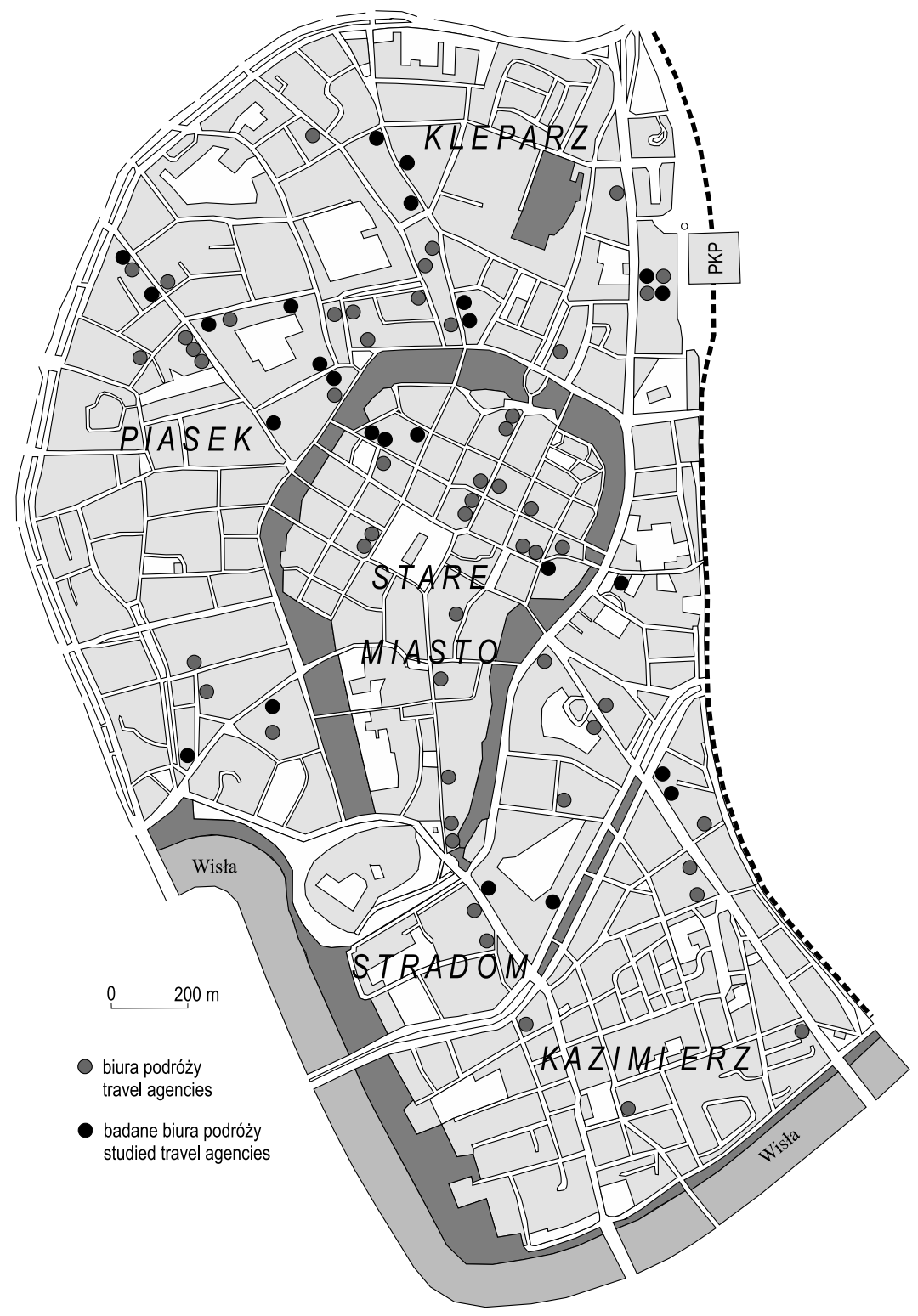

Ryc. 1. Rozmieszczenie biur podróży na krakowskim Starym Mieście, w dzielnicach przylegających i Kazimierzu (stan na 31 maja 2019 r.)

Fig. 1. Location of travel agencies in the Old Town of Krakow, in adjacent districts and in Kazimierz (as of 31 May 2019) 


\section{Wyniki}

Biura podróży, które charakteryzowały się bardzo niską jakością obsługi klienta, uzyskując mniej niż $60 \%$ możliwych punktów, stanowiły $16 \%$ badanych obiektów (ryc. 2). Średnio co czwarta placówka (24\%) odznaczała się niską jakością obsługi, zdobywając 61-70\% punktów. Te biura, w których obsługa klienta została oceniona na średnim poziomie, otrzymały między 71 a $80 \%$ punktów. Stanowiły one $28 \%$ obiektów, w których przeprowadzono badania. Kolejną grupę tworzyło 24\% lokali. Jakość obsługi klienta została w nich wysoko oceniona (81-90\% punktów). Natomiast te biura podróży, które cechowały się bardzo wysoką jakością obsługi i osiągnęły między 91 a 100\% możliwych do uzyskania punktów stanowiły $8 \%$ grupę.

Badane biura podróży, w których obsługa klienta została oceniona na najwyższym poziomie, wchodzą w skład sieci ITAKA. Pierwsze z nich, znajdujące się przy ul. Karmelickiej, osiągnęło aż 95\% wszystkich punktów, drugie, mieszczące się przy ul. Stradomskiej, niewiele mniej-92\% (ryc. 3). Wyróżnić należy także dwa biura charakteryzujące się wysoką jakością obsługi - W stronę Słońca (ul. Starowiślna) i KONTYNENT (ul. Długa). Oba otrzymały po $89 \%$ punktów. Z kolei placówki cechujące się bardzo niską obsługą klienta to Damar (ul. Grabarska) i Skarpa Travel (ul. Dietla), które uzyskały jedynie po $48 \%$ punktów oraz Jordan Group (ul. Długa) i Sol Tours (ul. Św. Marka), otrzymały one kolejno 53\% i 55\% możliwych do zdobycia punktów. Średni odsetek uzyskanych punktów w ocenie jakości obsługi klienta w krakowskich biurach podróży wynosił 73\%. Istotne różnice pojawiły się jednak w ocenie biur sieciowych i niesieciowych. Średnia ocena sieciowych biur podróży kształtowała się na poziomie $82 \%$, a niesieciowych $-70 \%$.

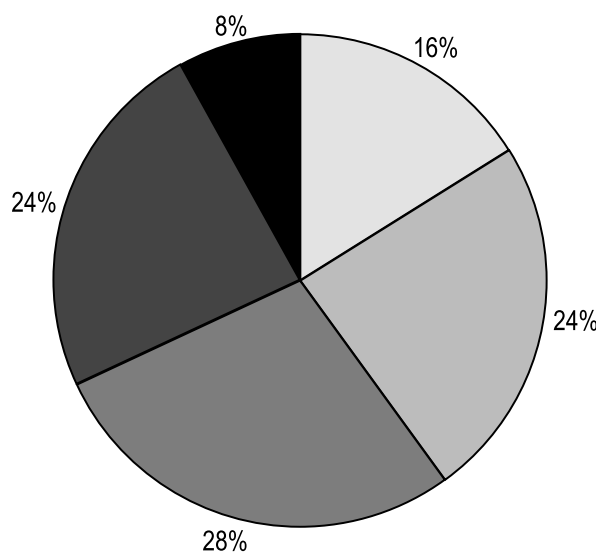

Jakość obsługi klienta Quality of customer service

\begin{tabular}{|l|l}
\hline & bardzo niska / very low \\
& niska / low \\
\hline & średnia / average \\
& wysoka / high \\
& bardzo wysoka / very high
\end{tabular}

Ryc. 2. Jakość obsługi klienta w badanych biurach podróży w Krakowie $(\mathrm{N}=25)$

Fig. 2. Quality of customer service in the studied travel agencies in Krakow ( $\mathrm{N}=25)$ 


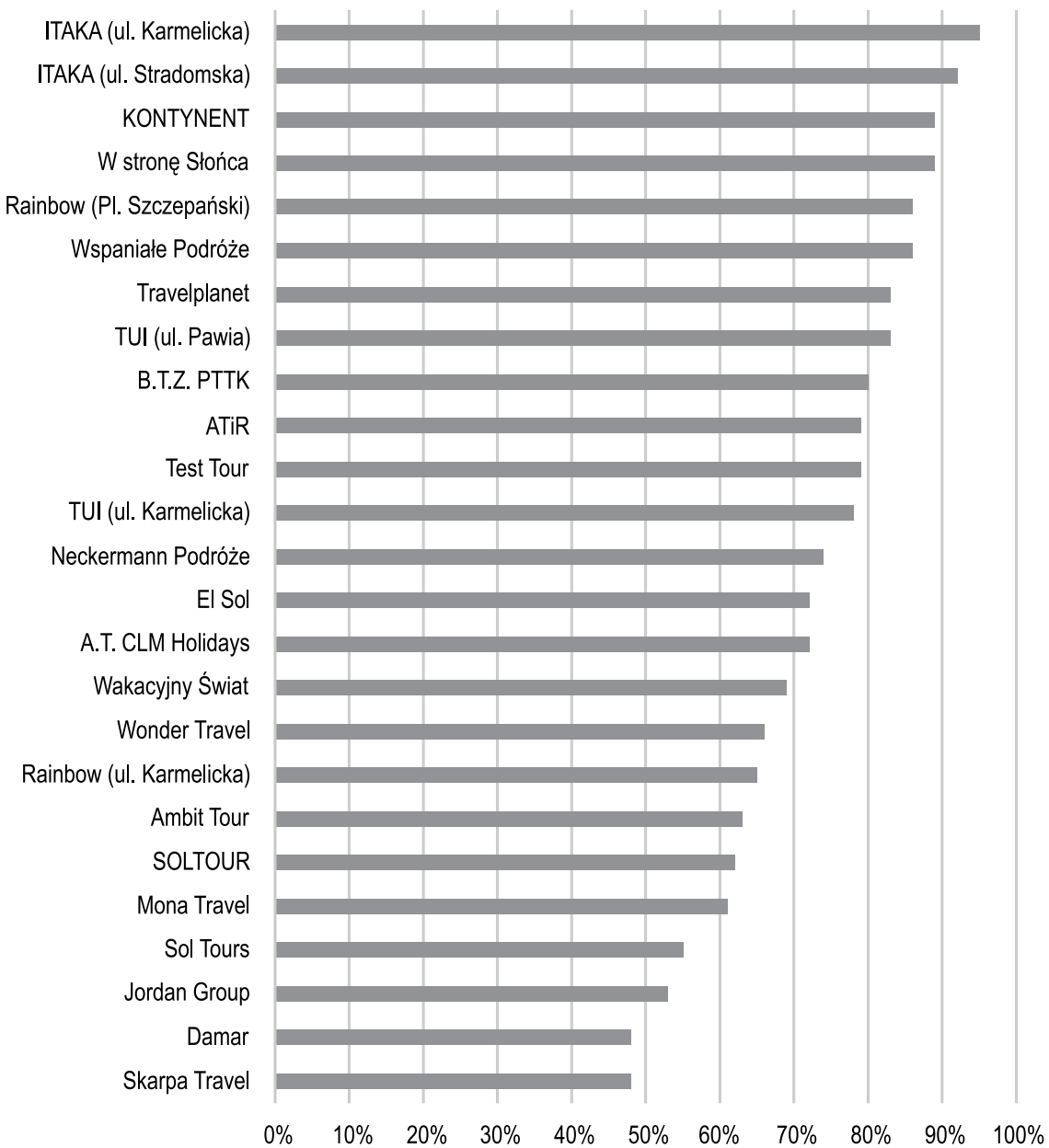

Ryc. 3. Odsetek uzyskanych punktów przez badane biura podróży w Krakowie w ocenie jakości obsługi klienta $(\mathrm{N}=25)$

Fig. 3. Percentage of points obtained by the studied travel agencies in Krakow in assessing the quality of customer service $(\mathrm{N}=25)$

Źródto: opracowanie własne na podstawie Zaremba (2019).

Source: authors' own study based on Zaremba (2019). 
Pierwszym ocenianym przez „tajemniczego klienta” elementem był wygląd i zagospodarowanie otoczenia biur podróży. Zwracano uwagę przede wszystkim na czystość wokół placówki, sposób jej oznakowania, udogodnienia dla osób niepełnosprawnych i tych, którzy poruszają się własnym samochodem. W większości (88\%) przypadków przed wejściem do biura było czysto i panował tam porządek. Wszystkie placówki zostały dobrze oznaczone, ich szyldy wisiały w widocznych miejscach. $\mathrm{Na}$ drzwiach prawie wszystkich $(96 \%)$ badanych biur podróży umieszczona była czytelna informacja o godzinach ich otwarcia w ciągu dnia i tygodnia. Niestety, niewielka liczba biur (16\%) została dostosowana do przyjęcia osób niepełnosprawnych. Nieliczne obiekty były wyposażone w podjazdy dla osób poruszających się na wózkach inwalidzkich, szerokie drzwi wejściowe oraz przestronne pomieszczenia. Z kolei zaparkowanie samochodu w pobliżu odwiedzanego lokalu było możliwe jedynie w $40 \%$ przypadków.

Kolejnym zadaniem „tajemniczego klienta” było dokonanie oceny witryn biur podróży pod względem ich czystości oraz przejrzystości, aktualności i atrakcyjności prezentowanych w nich ofert. Prawie wszystkie biura (96\%) miały witryny, w których przedstawiano oferty wyjazdów turystycznych. Nieco ponad połowa (56\%) badanych placówek mogła pochwalić się czystą i zadbaną witryną. W większości przypadków (84\%) wywieszane oferty były aktualne. Wśród nich, w $96 \%$ placówek, można było znaleźć także oferty promocyjne. Niestety, w niektórych lokalach (28\%) witryny te były nieprzejrzyste, co było spowodowane zbyt dużą liczbą ofert i innych informacji, często umieszczanych zbyt blisko siebie. Ponad połowa gablot informacyjnych (52\%) nie prezentowała się atrakcyjnie i nie przykuwała uwagi swoim wyglądem.

Celem następnego etapu była weryfikacja wystroju i zagospodarowania wnętrza badanych placówek. Audytor zwracał uwagę na czystość, porządek i wystrój pomieszczenia oraz biurek pracowników, warunki akustyczne, oświetleniowe i inne, rodzaj i jakość elementów wyposażenia i dekoracji, obecność materiałów reklamowych. Wewnątrz biur było przeważnie czysto i schludnie (84\%). Wystrój 64\% lokali był dość przyjemny i adekwatny do prowadzonej działalności. W większości biur (88\%) elementy wyposażenia były odpowiednie, a dekoracje dość atrakcyjne. Biurka pracowników zazwyczaj były czyste (84\%), jednakże do wielu (36\%) „tajemniczy klient” miał zastrzeżenia, co do panującego na nich porządku. Średnio w co trzecim lokalu (32\%) brakowało stojaków lub regałów z katalogami i innymi materiałami reklamowymi. Oświetlenie niektórych obiektów (12\%) było nieodpowiednie, w środku było zbyt ciemno i ponuro, co powodowało senność oraz utrudniało czytanie i obserwację. W średnio co czwartej placówce (24\%) istniał problem akustyczny. Spowodowany był głównie położeniem niektórych lokali przy ruchliwych ulicach. Hałas dokuczał również w biurach podróży zlokalizowanych w centrach handlowych. W jednym z badanych biur, w trakcie obsługi jeden z pracowników odkurzał zaplecze. Dźwięk odkurzacza docierał do biura, utrudniając rozmowę. Problem dźwiękowy pojawił się 
także w obiekcie, w którego ścianie zamontowano bankomat co chwilę wydający nieprzyjemne dźwięki.

Kolejny element oceniany przez „tajemniczego klienta” odnosił się do wyglądu pracowników. Osoba przeprowadzająca badanie zwracała uwagę na ubiór oraz zadbanie personelu obsługującego klientów. Wygląd pracowników przeważnie nie budził zastrzeżeń. Wszyscy byli ubrani schludnie, jednak tylko $68 \%$ z nich - elegancko (reprezentacyjnie, np. garnitur, garsonka, kostium, koszula). Zawsze mieli czyste, wyprasowane i praktyczne ubranie oraz czyste i odpowiednie do miejsca pracy obuwie. Firmowe uniformy miało na sobie jedynie $28 \%$ badanych osób. Byli oni zazwyczaj przedstawicielami sieciowych biur podróży. Większość pracowników (92\%) wyglądała na ogólnie zadbanych. Prawie wszyscy mieli czyste i uczesane włosy (96\%), zadbane dłonie i paznokcie (92\%) oraz, w przypadku kobiet, delikatny makijaż (96\%). Najsłabiej została oceniona kwestia używania przez pracowników identyfikatorów. Miała je średnio co czwarta osoba (24\%). Identyfikatory mieli tylko pracownicy sieciowych biur podróży.

W dalszej części audytu „tajemniczy klient” miał za zadanie dokonać oceny zachowania i kultury osobistej personelu. Ta część badań została podzielona na trzy etapy. Celem pierwszego etapu była weryfikacja początkowego kontaktu konsultanta z klientem, zaraz po wejściu klienta do biura podróży. W drugim etapie zwracano uwagę na sposób prowadzenia rozmowy przez pracownika podczas prezentowania oferty. Trzeci etap tej części odnosił się do umiejętności personelu dotyczących zakończenia rozmowy i pożegnania klienta.

Po wejściu do prawie wszystkich (96\%) badanych placówek, klient od razu został zauważony przez obsługę. W większości biur (80\%) powitano go uśmiechem, któremu towarzyszyła formuła powitalna wypowiadana przez pracownika. W pojedynczych przypadkach $(8 \%)$ personel nie interesował się klientem, dlatego musiał on sam jako pierwszy nawiązać kontakt z konsultantem. Jedynie $68 \%$ osób poddawanych ocenie wskazało gościowi gestem lub słowem miejsce, gdzie może usiąść. W średnio co piątym lokalu (20\%) pracownicy nie wykazywali się inicjatywą zaoferowania wchodzącej osobie pomocy. Tylko w 56\% placówek personel jako pierwszy rozpoczął rozmowę z klientem. W dwóch biurach podróży konsultanci przedstawili się, a w jednym zaproponowano klientowi coś do picia. W wielu przypadkach $(40 \%)$ pracownik był gotowy do służenia klientowi pomocą od pierwszej chwili jego wejścia do lokalu. Pozostałe sytuacje, w których ,tajemniczy klient” zastał pracowników to: prace biurowe (24\%), obsługa innych klientów (16\%), rozmowa telefoniczna (12\%) oraz czynności pozasłużbowe $(8 \%)$.

W trakcie prowadzenia rozmowy wszyscy konsultanci byli uprzejmi i życzliwi. Używali poprawnego języka. Mówili wyraźnie i spokojnie. Ich ton głosu był odpowiedni (88\%). Większość z nich (96\%) wyrażała się w sposób zrozumiały dla klienta. Umiejętnością słuchania drugiej osoby wykazało się 84\% badanych. Niestety, średnio 
co piąty pracownik (20\%) nie przeprosił klienta za przerwanie rozmowy, spowodowane koniecznością odebrania dzwoniącego telefonu.

Na zakończenie rozmowy $36 \%$ konsultantów wręczyło z własnej inicjatywy klientowi swoją wizytówkę. Ponad połowa z nich (56\%) poprosiła go o podanie adresu e-mail w celu dalszego kontaktu lub przesłania ofert. W co piątym biurze (20\%) nie przekazano klientowi oferty ani w wersji papierowej, ani nie przesłano jej pocztą elektroniczną. Każdy pracownik pożegnał się słownie z klientem, jednak tylko $40 \%$ z nich podziękowało za przyjście do danego biura podróży, a 52\% - zaprosiło do ponownego przyjścia.

Ważnym zadaniem „tajemniczego klienta” było także zweryfikowanie umiejętności pracowników co do badania potrzeb klienta w celu dostosowania odpowiedniej oferty, umiejętności przekazywania przez nich informacji oraz sprawdzenie kompetencji merytorycznych konsultantów w trakcie przedstawiania propozycji wyjazdów. Na początku rozmowy jedynie $60 \%$ pracowników biur podróży zadało klientowi kilka pytań wstępnych, by rozpoznać jego potrzeby. O kierunek wyjazdu, jaki preferowałby klient, zapytało $88 \%$ z nich, ale o budżet, jaki klient planuje przeznaczyć na wyjazd, już tylko 60\%. W trakcie trwania rozmowy nieco ponad 2/3 (68\%) konsultantów zadawało pytania otwarte, aby jak najlepiej dopasować ofertę do preferencji klienta. Większość pracowników (88\%) przedstawiła klientowi więcej niż dwie propozycje wyjazdów. Podczas omawiania ofert konsultanci najczęściej wspomagali się zdjęciami, prezentowanymi na monitorze komputera lub w katalogach (92\%), do których w większości przypadków (80\%) osoba przeprowadzająca badanie miała swobodny dostęp. „Tajemniczy klient” zwrócił uwagę, że w średnio co trzecim biurze (32\%) nie przekazano mu wszystkich niezbędnych informacji związanych z oferowanym wyjazdem turystycznym, takich jak: termin, cena, świadczenia wliczone w cenę itp. Zastrzeżenia miał także co do jakości udzielanych informacji. Aż 2/3 (68\%) konsultantów nie przedstawiło szczegółowych informacji na temat ofert, a w 56\% przypadków informacje te nie były wyczerpujące. Podczas rozmowy tylko $72 \%$ pracowników wykazało się wiedzą turystyczną, z kolei aż $40 \%$ z nich nie miało odpowiedniej wiedzy geograficznej.

Po wypełnieniu głównych części kwestionariusza audytor uzupełniał subiektywną część ankiety, odnoszącą się do jego odczuć, jakie miał podczas wizyty w danej placówce. W prawie 2/3 (64\%) biur był zadowolony z obsługi, wróciłby do nich ponownie i zaproponowałby dobremu znajomemu skorzystanie z usług tych biur. W aż 88\% przypadków odniósł wrażenie, że obsługa była chętna do pomocy. Jednakże tylko średnio w co szóstej placówce (16\%) w trakcie wizyty miał odczucie, że podchodzi się do niego indywidualnie i jest traktowany jak ktoś wyjątkowy.

Obszary obsługi klienta najlepiej ocenione podczas badań mystery shopping w biurach podróży w Krakowie odnoszą się do zachowania i kultury osobistej konsultantów podczas prowadzenia rozmowy z klientem $(91 \%)$ oraz wyglądu personelu (85\%) (tab. 1). 
Tab. 1. Ocena poszczególnych elementów obsługi klienta w badanych krakowskich biurach podróży $(\mathrm{N}=25)$

Table 1. Assessment of individual elements of customer service in the studied travel agencies in Krakow $(\mathrm{N}=25)$

\begin{tabular}{|c|c|c|}
\hline \multicolumn{2}{|c|}{$\begin{array}{l}\text { Oceniany element } \\
\text { Assessed element }\end{array}$} & $\begin{array}{c}\text { Odsetek pytań } \\
\text { ocenionych pozytywnie [\%] } \\
\text { Percentage of positive answers [\%] }\end{array}$ \\
\hline \multicolumn{2}{|c|}{$\begin{array}{l}\text { Wygląd i zagospodarowanie otoczenia lokalu } \\
\text { Appearance and development of the premises' surroundings }\end{array}$} & 75 \\
\hline \multicolumn{2}{|c|}{ Prezentacja witryny / Glass-case presentation } & 74 \\
\hline \multicolumn{2}{|c|}{$\begin{array}{l}\text { Wystrój i zagospodarowanie wnętrza lokalu } \\
\text { Interior design and arrangement of the premises }\end{array}$} & 80 \\
\hline \multicolumn{2}{|l|}{ Wygląd personelu / Staff appearance } & 85 \\
\hline \multirow{3}{*}{$\begin{array}{l}\text { Zachowanie i kultura osobista } \\
\text { personelu } \\
\text { Staff behavior and personal culture }\end{array}$} & $\begin{array}{l}\text { Wejście klienta do biura } \\
\text { Customer entrance to the office }\end{array}$ & 64 \\
\hline & $\begin{array}{l}\text { Prowadzenie rozmowy } \\
\text { Conducting the conversation }\end{array}$ & 91 \\
\hline & $\begin{array}{l}\text { Zakończenie rozmowy } \\
\text { i pożegnanie klienta } \\
\text { End of the conversation and } \\
\text { saying goodbye to the customer }\end{array}$ & 59 \\
\hline \multicolumn{2}{|c|}{$\begin{array}{l}\text { Umiejętności personelu odnośnie do badania potrzeb klienta } \\
\text { i przedstawienia oferty } \\
\text { Staff skills with regard to investigating customer needs }\end{array}$} & 68 \\
\hline \multicolumn{2}{|c|}{$\begin{array}{l}\text { Zadowolenie klienta z obsługi w biurze podróży } \\
\text { Customer satisfaction with service in the travel agency }\end{array}$} & 57 \\
\hline
\end{tabular}

Z kolei elementy, które zostały najsłabiej ocenione i wymagają szczególnej poprawy dotyczą: zachowania i kultury osobistej pracowników w momencie wejścia klienta do biura oraz przy zakończeniu rozmowy i pożegnaniu klienta. W przypadku pierwszego wymienionego w poprzednim zdaniu bloku tematycznego 36\% pytań zostało ocenionych negatywnie, a w przypadku drugiego $-41 \%$.

\section{Dyskusja i wnioski}

Większość biur podróży specjalizujących się w turystyce przyjazdowej zlokalizowana jest na Starym Mieście. Ich rozmieszczenie, przede wszystkim przy ul. Floriańskiej i ul. Grodzkiej, ściśle nawiązuje do przebiegu tzw. Drogi Królewskiej, najpopularniejszej trasy turystycznej Krakowa, przy której znajdują się główne zabytki tego miasta. Trasę tę przemierza codziennie tysiące turystów pragnących poznać Kraków i jego okolice. Natomiast wiele biur podróży, które specjalizują się w turystyce 
wyjazdowej, położonych jest przy ulicach: Karmelickiej, Długiej, Starowiślnej i Stradomskiej, będących ważnymi ciągami komunikacyjnymi, usługowymi i handlowymi oraz w Galerii Krakowskiej - największym centrum handlowo-usługowym tej części Krakowa. Wymienionymi ulicami, którymi biegną linie tramwajowe oraz przez Galerię Krakowską, położoną przy Dworcu Głównym Kolejowym i Dworcu Autobusowym, codziennie przemieszczają się rzesze mieszkańców miasta i okolic oraz studentów podróżujących do pracy, szkoły lub na uczelnię. Zasadne wydaje się zatem lokalizowanie biur podróży oferujących swoje usługi głównie turystom przyjezdnym przy ulicach i w miejscach najpopularniejszych pod względem turystycznym, a tych specjalizujących się w turystyce wyjazdowej-przy ulicach będących głównymi ciągami komunikacyjnymi, usługowymi i handlowymi, gdyż tam znajduje się najwięcej potencjalnych klientów.

Jakość obsługi klienta w krakowskich biurach podróży jest zróżnicowana. Placówki, które zostały ocenione wysoko lub bardzo wysoko stanowią $32 \%$ badanych obiektów, a te sklasyfikowane nisko i bardzo nisko - aż 40\%. Średni odsetek uzyskanych punktów w ocenie poziomu obsługi klienta wyniósł 73\%. W 1997 r. Dziadkowiec (2000) przeprowadziła podobne badania w krakowskich biurach podróży, korzystając z tej samej metody. Wyniki były następujące: $46 \%$ biur charakteryzowało się wysoką i bardzo wysoką jakością obsługi, natomiast 34\% - niską i bardzo niską. Z kolei średnia ocena wszystkich badanych firm kształtowała się na poziomie 68\%. Mając na uwadze powyższe wyniki, wydaje się, że jakość obsługi klienta w biurach podróży w Krakowie jest obecnie na niższym poziomie niż w latach 90. XX w. Pomimo iż średnia uzyskanych punktów przez biura w badaniach przeprowadzonych w $2019 \mathrm{r}$. jest o 5\% wyższa niż w 1997 r., to wydaje się, że różnica ta jest zdecydowanie zbyt mała, by można mówić o wzroście jakości obsługi. Biorąc pod uwagę przemiany społeczne i ekonomiczne, jakie nastąpiły w Polsce pomiędzy 1997 a 2019 r., tj. w ciągu 22 lat, i stale następujący wzrost wymagań klientów, należy stwierdzić, że jakość obsługi w biurach podróży jest na coraz niższym i niesatysfakcjonującym klienta poziomie. $Z$ punktu widzenia rozwoju bądź nawet przetrwania firmy na coraz bardziej konkurencyjnym rynku, zasadne wydaje się zatem badanie obsługi klienta w krakowskich biurach podróży i odpowiednio wczesne reagowanie przez właścicieli tych przedsiębiorstw na spadek jej jakości.

Poziom obsługi klienta w sieciowych biurach podróży prezentuje się zdecydowanie lepiej niż w biurach niesieciowych. Średni odsetek punktów uzyskanych przez placówki sieciowe wyniósł 82\%, a przez niesieciowe - 70\%. Biura podróży funkcjonujące w ramach jednej sieci mają określone standardy obsługi klienta, jednakowe dla wszystkich oddziałów. Zawarte są w nich szczegółowe instrukcje odnoszące się m.in. do wystroju placówki, ubioru pracowników, ich obuwia, fryzur, wyglądu dłoni, makijażu, możliwości noszenia biżuterii i tatuażu. Określają one także wzorce zachowania, sposób prowadzenia bezpośredniej, jak i telefonicznej rozmowy 
z klientem oraz zasady prezentowania oferty. W celu sprostania jak najwyższym standardom obsługi klienta, pracownicy takich firm są niejednokrotnie szkoleni i systematycznie poddawani ocenie. Na zlecenie franczyzodawców kilka razy w roku w każdej placówce są przeprowadzane badania „tajemniczego klienta” oraz badania ankietowe wśród klientów, którzy skorzystali z usług danego biura. Osoby, które cyklicznie osiągają niskie oceny w badaniach ponoszą konsekwencje finansowe i związane z zatrudnieniem.

Najlepiej ocenionymi podczas badań obszarami obsługi klienta w biurach podróży były wygląd pracowników oraz ich zachowanie i kultura osobista w trakcie prowadzenia rozmowy z klientem. Natomiast te segmenty obsługi, które wymagają szczególnej poprawy, odnoszą się do zachowania i kultury osobistej personelu w chwili wejścia klienta do biura oraz przy zakończeniu rozmowy i pożegnaniu klienta. Wątpliwości budziły także umiejętności konsultantów co do badania potrzeb klienta i przedstawiania oferty. Niektóre nieprofesjonalne zachowania pracowników w stosunku do klienta, związane m.in. z przywitaniem się, rozpoczęciem konwersacji, podziękowaniem za przyjście, pożegnaniem, wyrażeniem gotowości do dalszej współpracy, oraz słabe umiejętności personelu dotyczące rozpoznania potrzeb klienta i przedstawiania oferty wpłynęły na ogólne niezadowolenie klienta z obsługi średnio w co trzecim biurze podróży (36\%). Tylko w co szóstym badanym obiekcie (16\%) okazano mu maksimum zainteresowania i szacunku, traktowano go indywidualnie, jak kogoś najważniejszego, przez co czuł się doceniony i jak ktoś wyjątkowy.

Zaprezentowane w artykule wyniki badań mogą zostać wykorzystane w działalności biur podróży w całej Polsce w celu podniesienia jakości świadczonych usług w tych przedsiębiorstwach i sprostania wymaganiom zarządzania jakością TQM i normy ISO 9001. W celu rozpoznania tendencji odnoszących się do jakości obsługi klienta w biurach podróży zasadne wydaje się powtórzenie badań w przyszłości oraz dokonanie ocen porównawczych w relacji do innych miast w kraju. Prowadzenie badań jakości obsługi klienta w turystyce jest istotne z punktu widzenia zrównoważonego rozwoju biznesu turystycznego.

\section{Literatura:}

Atlas Miasta Krakowa, 1988, Instytut Geografii UJ, Wydział Geodezji i Gospodarki Gruntami Urzędu Miasta Krakowa, Kraków.

Baum T., Kokkranikal J., 2008, Zarzqdzanie zasobami ludzkimi w turystyce, [w:] L. Pender, R. Sharpley (red.), Zaræqdzanie turystykq, Polskie Wydawnictwo Ekonomiczne, Warszawa, 115-132.

Bielawa A., Frąś J., Gołębiowski M., 2009, Metoda SERVQUAL jako skuteczne naræędzie oceny jakości ustug, Studia i Prace Wydziału Nauk Ekonomicznych i Zarządzania, 12, 217-224. 
Chen R.J.C., Barrows C.W., 2015, Developing a Mystery Shopping measure to operate a sustainable restaurant business: The power of integrating with corporate executive Members' Feedback, Sustainability, 7, 12279-12294, DOI: 10.3390/su70912279.

Dyka M., 2018, 1 lipca 2018 r. wchodzi w życie nowa ustawa o ustugach turystycznych, https://www.legalniewsieci.pl/aktualnosci/1-lipca-2018-r-wchodzi-w-zycie-nowa-ustawao-uslugach-turystycznych-2 (dostęp: 29.02.2020).

Dziadkowiec J., 2000, Wykorzystanie programu Mystery Shopping w konsumenckiej ocenie jakości obstugi klienta w biurach turystycænych, Folia Turistica, 9, 69-87.

Dziadkowiec J., 2004, Mystery Shopping - metoda badania i oceny jakości ustug, Problemy Jakości, $10,24-27$.

Dziadkowiec J., 2006a, Procedura obstugi klienta w biuræe podróży, [w:] T. Sikora (red.), Klient w organizacji zarzqdzanej przez jakość, Akademia Ekonomiczna w Krakowie, Kraków, $152-156$.

Dziadkowiec J., 2006b, Wybrane metody badania i oceny jakości ustug, Zeszyty Naukowe Akademii Ekonomicznej w Krakowie, 717, 23-35.

Dziadkowiec J., 2011, Badanie jakości ustug świadczonych przez restauracje metodq ankietowa $i$ metodq mystery shopping, Zeszyty Naukowe Uniwersytetu Szczecińskiego. Problemy Zarządzania, Finansów i Marketingu, 22 (694), 22-44.

Dziadkowiec J., Rood A.S., 2010, Wykorzystanie metody Mystery Shopping do badań porównawczych ustug świadczonych przez restauracje, Problemy Jakości, 42, 37-42.

Gamble P., Jones P., 1991, Quality as a strategic issue, [w:] R. Teare, A. Boer (red.), Strategic Hospitality Management, Cassell, London, 72-82.

Jackiewicz A., Dębski M., 2015, Lojalność konsumentów jako źródto præewagi konkurencyjnej prwedsiębiorstwa hotelarskiego, Prace Naukowe Uniwersytetu Ekonomicznego we Wrocławiu, 379, 186-200.

Kachniewska M., 2004, ISO 9001 w przedsiębiorstwie turystycznym, Wyższa Szkoła Handlu i Prawa, Warszawa.

Karaszewski R., 2001, SERVQUAL - metoda badania jakości swiadczonych ustug, Problemy Jakości, 5, 8-10.

Konieczna-Domańska A., 2008, Biura podróży na rynku turystycznym, Wydawnictwo Naukowe PWN, Warszawa.

Kosmaczewska J., 2011, Wykorzystanie techniki e-mail mystery shopping w ocenie zarzqdzania jakościq informacji turystycznej na przyktadzie stowarzyszeń agroturystycznych, [w:] A. Rapacz (red.), Gospodarka turystyczna w regionie, Wydawnictwo Uniwersytetu Ekonomicznego we Wrocławiu, Wrocław, 269-279.

Kruczek Z., Cieszkowska K., 2017, Możliwości sastosowania metody mystery shopping w ocenie jakości ustug turystycznych. Studium przypadku - Termy w Biatce Tatrzańskiej, Ekonomiczne Problemy Turystyki, 2 (38), 47-60.

Kruczek Z., Szromek A.R., 2014, A survey of the attractiveness of museum services in Krakow: A proposal for methodology, Folia Turistica, 33, 110-131. 
Krzesiwo K., 2014, Rowwój i funkcjonowanie stacji narciarskich w polskich Karpatach, Instytut Geografii i Gospodarki Przestrzennej UJ, Kraków.

Krzesiwo K., 2018, Ocena wybranych dziatan promocyjnych ośrodków narciarskich w Polsce - przykład Ośrodka Narciarskiego Kotelnica Biatczańska w Biatce Tatræańskiej, Folia Turistica, 48, 261-281, DOI: 10.5604/01.3001.0012.7704.

Lovett M., Peres R., Shachar R., 2013, On brands and word-of-mouth, Journal of Marketing Research, 50 (4), 427-444.

Mazurek-Kusiak A., 2012, Popyt na ustugi tradycyjnych biur podróży a jakość obstugi klienta na przyktadzie lubelskiego rynku biur podrózy, Zeszyty Naukowe Uniwersytetu Szczecińskiego. Ekonomiczne Problemy Usług, 84, 461-469.

Mazurkiewicz-Pizło A., Pizło W., 2018, Tajemniczy klient jako metoda badawcza - wybrane problemy, Polityki Europejskie, Finanse i Marketing, 20 (69), 112-126, DOI: 10.22630/ PEFIM.2018.20.69.33.

Mroczkowska M., Pawlicz A., 2012, Liczba pokoi obiektu hotelarskiego jako determinanta jakości obstugi klienta, Zeszyty Naukowe Uniwersytetu Szczecińskiego. Ekonomiczne Problemy Turystyki, 20, 103-113.

Panasiuk A., 2006, Jakość obstugi ruchu turystycznego, [w:] B. Meyer (red.), Obstuga ruchu turystycznego, Wydawnictwo Naukowe PWN, Warszawa, 220-233.

Pawlusiński R., 2007, Biura podróży, [w:] W. Kurek (red.), Turystyka, Wydawnictwo Naukowe PWN, Warszawa, 177-181.

Pawlusiński R., 2011, Baza towarzyszqca, [w:] M. Mika (red.), Kraków jako ośrodek turystyczny, Instytut Geografii i Gospodarki Przestrzennej UJ, Kraków, 199-218.

Poon A., 1993, Tourism, technology and competitive strategies, CABI Publishing, Wallingford.

Rapert M.I., Wren B.M., 1998, Service quality as a competitive opportunity, The Journal of Services Marketing, 3 (12), 223-235.

Raport z badan mystery shopping w placówkach Informacji Turystycznej dla Polskiej Organizacji Turystycznej, 2013, Public Profits Sp. z o.o., Poznań.

Rosen E., 2000, The anatomy of busz: How to create word of mouth marketing, Doubleday, Nowy Jork.

Stoma M., 2012, Modele i metody pomiaru jakości ustug, Wydawnictwo Q\&R Polska, Lublin.

Su Ch., Tsai Ch., 2014, The implication of Mystery Shopping Program in chain restaurants: Supervisors' perception, Journal of Foodservice Business Research, 17 (4), 267-282, DOI: 10.1080/15378020.2014.945886.

Szostak D., 2007, Mierniki jakości ustug hotelarskich i gastronomicznych, [w:] A. Panasiuk (red.), Jakośc ustug turystycznych, Uniwersytet Szczeciński, Szczecin, 71-99.

Szostak D., Panasiuk A., 2007, Podstawowe zagadnienia dotyczqce jakości ustug turystycznych, [w:] A. Panasiuk (red.), Jakość ustug turystycznych, Uniwersytet Szczeciński, Szczecin, 12-27. Szymańska E., 2008, Biura podrózy na rynku ustug turystycznych, Wydawnictwo Politechniki Białostockiej, Białystok. 
Tajemniczy klient w jednostce Informacji Turystycznej - raport z badań, 2019, Polska Organizacja Turystyczna, Agencja Badawcza COGNITIVA, Poznań, https://www.pot.gov.pl/ attachments/article/1804/Raport_Tajemniczy_Klient_2019.pdf (dostęp: 03.03.2020).

Tajemniczy klient w placówce IT - raport \& badań dla Polskiej Organizacji Turystycænej, 2017, Agencja Badawcza COGNITIVA, Poznań, https://www.pot.gov.pl/attachments/article/1804/raporttajemniczy-klient-informacja-turystyczna-2017.pdf (dostęp: 03.03.2020).

Tokarz A., 2007, Personel turystyczny, [w:] A. Panasiuk (re d.), Marketing ustug turystycznych, Wydawnictwo Naukowe PWN, Warszawa, 146-163.

Urbaniak A.M., 2013, Zastosowanie metody SERVQUAL do oceny jakości ustug rekreacyjnych, Zeszyty Naukowe Uczelni Vistula, 32, 29-38.

Ustawa o imprezach turystyc:nych i powiqzanych ustugach turystyc*nych \& dnia 24 listopada 2017 r. (Dz.U. 2017 poz. 2361).

Ustawa o ustugach turystycznych * dnia 29 sierpnia 1997 r. (Dz.U. $1997 \mathrm{Nr} 133$ poz. 884).

Waloryzacja przestrzeni miejskiej Krakowa dla potrzeb turystyki. Raport końcowy, 2008, Instytut Geografii i Gospodarki Przestrzennej UJ, Kraków.

Wszendybył-Skulska E., 2015, The Mystery Shopper Technique as a way of improving hotel gastronomy services, Production Engineering Archives, 7 (2), 20-24.

Zaremba A., 2019, Ocena jakości obstugi klienta w krakowskich biurach podróży (praca magisterska), Uniwersytet Pedagogiczny w Krakowie, Kraków.

Żemła M., 2010, Wartość dla klienta w procesie kštattowania konkurencyjności obszaru recepcji turystycznej, Górnośląska Wyższa Szkoła Handlowa im. Wojciecha Korfantego, Katowice.

\author{
Kinga Kræesiwo, Anna Zaremba \\ Uniwersytet Pedagogicæny w Krakowie \\ Instytut Geografii, Katedra Turystyki i Badań Regionalnych \\ ul. Podchorqzych 2, 30-084 Kraków \\ kinga.krwesiwo@up.krakow.pl \\ anna.zaremba@onet.pl
}


